\title{
Neurological impairments in COVID-19 pandemic
}

\author{
Ivana Bjelobaba, Selma Kanazir \\ Department for Neurobiology, Institute \\ for Biological Research "Sinisa Stankovic" \\ - National Institute of Republic of Serbia, \\ University of Belgrade, Belgrade, Serbia \\ Corresponding author: \\ Ivana Bjelobaba
}

Department for Neurobiology, Institute for Biological Research "Sinisa Stankovic" National Institute of Republic of Serbia, Bulevar despota Stefana 142, 11000 Belgrade, Serbia. Phone: +381 112078 340;

Fax: +381 112078 433;

E-mail address:

ivana.bjelobaba@ibiss.bg.ac.rs

Received 07 September 2020

Accepted 12 October 2020

\begin{abstract}
The growing body of data implies that SARS-CoV-2 infection may affect the nervous system. We here present a short, taciturn overview of described neurological impairments related to SARS-CoV-2 infection. While it is obvious that neurological impairments can be diagnosed in a portion of COVID-19 patients, evidence of SARS-CoV-2 neurovirulence in humans is still lacking. The existing data on the incidence of neurological impairments among COVID-19 patients is highly variable, probably because they (most often) come from small, single-center retrospective studies. These data are practically published in real-time, and the question remains when larger studies will be available, given that the pandemic is continuing. We here also shortly address the other issues related to neurological disorders and COVID-19 pandemic, including the concern for people with existing chronic neurological disorders and possible long-term neurological consequences of SARS-CoV-2 infection.
\end{abstract}

Key words: SARS-CoV-2; COVID-19; Neurotropism; Neurological impairment.

\section{IS SARS-COV-2 NEUROTROPIC?}

Coronaviruses are a large family of single-strand RNA viruses, which commonly display spike proteins at their envelopes (electron microscopy visualization of these protrusions helped to name them). Four genuses of coronaviruses are described; almost exclusively, mammals host members of alpha and beta genuses [1]. It is probable that all coronaviruses have a zoonotic origin. Origins of mammalian coronaviruses involve Asian and African continents, with bats serving as the largest viral reservoirs [2]. Human epidemic Severe Acute Respiratory Syndrome coronaviruses SARS-CoV and SARSCov-2 belong to betacoronaviruses [1]. Coronaviruses can infect the respiratory, gastrointestinal, hepatic, and central nervous system of other animals (livestock and many wild animal species) and humans. The rapidly accumulating data imply that, in humans, SARS-Cov-2 does not affect only the respiratory tract. Rather, there is a variety of symptoms, including anosmia, ageusia, headache, confusion, delirium, nausea, and diarrhea. Since recently, these more or less common symptoms are often blamed on virus-cell tropism and neurotropism.

The genome of Coronaviruses is polyadenylated and capped, single-stranded positive-sense RNA. The genome of Coronaviruses is unusually big when com- pared to other RNA viruses and contains at least six open reading frames, coding for structural (S-spike, E-envelope, M-membrane, $\mathrm{N}$-nucleocapsid) and nonstructural proteins. Specific coronaviruses also code for some specific structural or non-structural proteins like HE protein in Murine Hepatitis Virus (MHV). Spike proteins are the most important coronavirus proteins for cell tropism of coronaviruses and attachment to cell surface receptors. This enables membrane fusion and entry of the viral genome into the cell [1]. SARSCoV-2 spike proteins also use this ability to attach to a specific cell receptor. Like SARS-CoV, but with a greater binding efficiency, SARS-CoV-2 reaches the cells by angiotensin-converting enzyme 2 (ACE2) [3]. However, in some strains of MHV, HE protein is also mediating cell tropism and neurotropism [4]. In animals, coronavirus neurotropism is commonly seen in MHV and feline infectious peritonitis virus infections [5]. Moreover, certain strains of MHV serve as models for studying encephalitis and demyelinating diseases [6]. In humans, coronaviruses have been associated with multiple sclerosis development $[7,8]$, but the interest for coronaviruses neurotropism was recently sparked by the novel SARS-CoV-2 virus.

Multiple points of entry to the central nervous system (CNS) for SARS-CoV-2 have been proposed, and up to now, all mechanisms of invasion are thought to be 
involving ACE2. Importantly, the ACE2 mediates cell tropism in SARS-CoV and SARS-CoV-2, is expressed in human and in mouse brain [9]. ACE2 is present in human nasal epithelia, and its expression seems to vary between populations and increases with age [10]. Thus, the olfactory pathway is considered as a possible route of entry to the CNS. In addition, the presence of anosmia in great many COVID-19 patients implies that rare neurological complications may originate from there. Indeed, the olfactory pathway and trigeminal nerve (both of which innervate the nose) are considered as the routes of coronaviruses entry to the brain [11].

The importance of coronavirus binding to ACE2 for neurovirulence was shown in mouse animal models. Generally, mice fail to develop serious complications or neuropathology when inoculated with SARS-CoV [12], even though ACE2 is highly expressed in the mouse olfactory bulb [9]. However, mouse transgenes for human ACE2 display a lethal form of the disease when infected intranasally. This form of the disease also involves a rapid and extensive viral spread throughout the CNS despite low expression of the transgenic receptor in the brain [13]. No obvious inflammation was observed, although viral spread was followed by neuronal cell death [12-14]. In these studies, the point of viral entry to the brain was indeed proposed to be the olfactory bulb. In support of this hypothesis, the unilateral ablation of the olfactory bulb in mice prevents MHV CNS invasion on that side of the brain [11].

Similarly, recent studies in the same ACE2 transgenic mouse model imply more severe SARS-CoV-2 infection and higher replication in various organs, including the brain [15]. Even when human ACE2 is expressed in mice lungs only, moderate replication of SARS-CoV-2 was also observed in the brain [16].

However, there is no strong evidence of the presence of ACE2 mRNA in the human olfactory bulb [9]. Another study found ACE2 protein in the olfactory bulb but could not localize it in neurons [17]. Furthermore, ACE2 is localized in glial cells $[9,17]$, but the presence of SARS-CoV was reported in neurons only $[18,19]$. This prompted the hypotheses that SARS-CoV and SARS-CoV-2 neuroinvasion could be mediated by vagal afferent innervation of the pulmonary system $[20,21]$ or primary afferents of the trigeminal nerve [22].

An alternative route was recently proposed. Given the high expression of ACE2 at the enterocytes of the small intestine and colon and the presence of SARSCoV-2 in the gut, involvement of the enteric nervous system in the virus neurotropism was suggested [22, 23].

Nevertheless, there is little or no evidence of the presence of the virus in the brain in COVID-19 patients. Further, there is no direct and specific SARS-CoV-2 damage to the brain in autopsied patients [24-26].
Rather, the pattern of brain pathology resembles those found in patients with hypoxic respiratory failure, given that brain vascular injury is a common post-mortem and MRI finding [25, 27-29]. Some studies found SARSCoV-2 mRNA in the brain tissue; however, its low levels and the absence of specific histopathological findings implied that this mRNA comes from blood [26, 30]. A recent report tells of SARS-Cov-2 potential to invade human brain organoids and claims that SARS-CoV-2 spike protein can be detected by immunohistochemistry in the human brain [31]. Conversely, Pellegrini et al. [32] found that, in brain organoids, SARS-CoV-2 shows tropism for ACE2 expressing epithelial cells of choroid plexus, but no tropism for neurons or glial cells. Importantly, in order to reach the choroid plexus, the virus has to be present in the blood, which is a rare event (occurring in about 1\% of all COVID-19 patients) [33].

Interestingly, in the cerebrospinal fluid, the presence of SARS-CoV-2 RNA is not a common finding [3437], although in some patients, it shows high titers of anti-SARS-CoV-2 antibodies [37].

Thus, the neuroinvasive potential of SARS-CoV-2 remains ambiguous, and it is quite possible that the majority of neurological complications come secondary to hypoxia and/or severe systemic inflammation. The reader of this review should also be aware that some of the literature cited here still needs to be peerreviewed and is currently available as preprint only (bioRxiv open-access platform).

\section{NEUROLOGICAL MANIFESTATIONS ARE ACCOMPANYING SARS-COV-2 INFECTIONS}

The growing body of data implies that neurological abnormalities may follow SARS-CoV-2 infection. Up to now, data is collected in case reports and observational retrospective studies. The major limitation of these studies is a small sample size coming from a single center; large scale observational studies on neurological disorders in SARS-CoV-2 are still lacking.

The first study on neurological manifestations came from Wuhan, the epicenter of the COVID-19 pandemic, and reported that over a third (36.4\%) of 214 patients with confirmed SARS-CoV-2 infection had some neurological symptoms [38]. The most common findings were dizziness (16,8\%), headaches (13.1\%), and cerebrovascular events (5.7\%, mostly in severe cases) [38].

Further retrospective studies that included critically ill patients also revealed wide spectra of neurological and neuropsychiatric complications [27, 39-42].

A recently published study reported the data obtained from the large TriNetX database, representing a global health collaborative clinical research platform collecting real-time electronic medical records data from a network of health care organizations from January 20th, 2020 (the first reported case in the 
USA) to June 10th, 2020. According to this database, out of more than 40000 COVID-19 patients analyzed, $22.5 \%$ of patients had neurological and neuropsychiatric manifestations. The neurological manifestations included headache $(3.7 \%)$, sleep disorders $(3.4 \%)$, encephalopathy $(2.3 \%)$, myalgia $(2.0 \%)$, pain $(1.8 \%)$, loss of taste and smell (1.2\%), stroke and transient ischemic attack (1.0\%) and seizures (0.6\%) [43]. A larger European survey done among neurologists from different countries revealed that headache $(61.9 \%)$, myalgia (50.4\%), anosmia (49.2\%), ageusia (39.8\%), impaired consciousness (29.3\%), psychomotor agitation (26.7\%), encephalopathy and acute cerebrovascular disorders $(21.0 \%)$, are the most frequently reported neurological symptoms. Less frequently, dysphagia (11.2\%), sleep disorders other than hypersomnia (10.7\%), peripheral nerve damage $(8.5 \%)$, seizures $(8.1 \%)$, ataxia $(7.4 \%)$, meningeal signs $(5.7 \%)$, movement disorders $(5.2 \%)$, and visual abnormalities (5.1\%) were described [44].

The neuropsychiatric issues remain beyond the scope of this short overview but deserve to be mentioned. The prolonged shutdowns, social distancing, and economic problems are probably going to take their toll in the long run and reflect on the mental health of people worldwide. Nalleballe et al. also reported on psychiatric manifestations in COVID-19 patients: anxiety and other related disorders were found in $4.6 \%$, mood disorders in $3.8 \%$, and suicidal ideation in $0.2 \%$ patients [ 43 ].

In general, neurological manifestations could be classified into CNS (dizziness, headache, impaired consciousness, acute cerebrovascular disease, ataxia, epilepsy and seizure, encephalopathy) and peripheral nervous system (PNS) manifestations (taste impairment- hypogeusia/ageusia, smell impairment- hyposmia/anosmia, vision impairment, nerve/muscle pain, and Guillain-Barre syndrome).

\section{CNS manifestations}

Headaches were reported as the most common neurological symptom with varying prevalence: $3,7 \%$ derived from TriNetX database analysis [43], whereas $8 \%$ is the mean prevalence derived from different studies [45]. Most likely, headaches are related to hypoxia and decreased cerebral blood flow [43].

Older COVID-19 patients with preexisting medical conditions and poor prognosis are more likely to experience impaired consciousness [46]. Impaired consciousness reported in 9\% of COVID-19 patients with poor prognosis [47], while the acute loss of consciousness was linked to a case of intracranial hemorrhage [48].

Seizures were found in around 0,6\% of patients [43], most likely are related to increased cytokine levels, but may also come as a rare adverse reaction to antiviral drugs or hydroxychloroquine [46].
Vascular diseases are common preexisting conditions in severe cases of SARS-CoV-2 infections [49]. Nevertheless, it is clear that a variety of acute cerebrovascular disease (CVD) events can be found among COVID-19 patients, including acute ischemic strokes and transient ischemic attack, a cerebral venous sinus thrombosis, and intracerebral hemorrhage. The incidence of CVD greatly varies across different studies, but the common finding is that acute ischemic stroke is the most prevalent one. The other reported CVD symptoms are sporadic and mostly found in severe COVID-19 patients with existing vascular comorbidities [46].

The COVID-19 patients with acute ischemic stroke usually have elevated blood levels of C-reactive protein, D-dimer, antiphospholipid antibodies $[41,49]$. Infection of the vascular endothelial cells (virus binding to ACE2 that is enriched in these cells) and subsequent damage to the vasculature, followed by inflammatory cytokine storm and impaired coagulation cascade, was proposed to be a candidate mechanism for stroke-like symptoms $[43,50]$.

Hypoxic brain damage was diagnosed in $20 \%$ of 113 deceased patients with SARS-CoV-2 infection [51]. In general, these events may be related to prolonged hypoxia, which induces blood-brain barrier disruption and micro-hemorrhagic insults to the nervous tissue [52]. This is in concordance with histopathological findings of ischemic changes and microglial activation, without extensive infiltration of inflammatory cells [30].

Sporadic cases of cerebellar ataxia $[53,54]$ and acute disseminated encephalomyelitis (ADEM) are also reported [55].

\section{PNS related disorders}

A partial or complete loss of sense of smell and/or taste is reported as the most common PNS related symptom among COVID-19 patients with varying incidence across the studies and between countries [56]. Hypoanosmia and hypoagueseia are common symptoms in many other respiratory infections and, as such, may not have been recognized as SARS-CoV-2 specific at first. Nevertheless, these symptoms come early in the course of the disease and may be the primary cause for alarm in COVID-19 patients [56]. Unlike for two similar human coronaviruses that cause Middle East respiratory syndrome and SARS-CoV, for SARS-CoV-2 firm evidence of infecting olfactory neurons (olfactory sensory neurons do not express ACE2) is still missing. Present data suggest that damage to the olfactory epithelium, rather than neuronal injury underlies clinical anosmia $[57,58]$, while high ACE2 expression in oral mucosa [59] may account for ageusia.

The rare autoimmune diseases of peripheral nerves, the Guillain-Barré syndrome (GBS), also known 
as acute inflammatory demyelinating polyneuropathy (AIDP), can be triggered by the SARS CoV-2 infection [60]. The symptoms are manifested as the muscle weakness of arms and legs, areflexia, facial weakness in some patients, and changes in sensation or pain, while the acute phase is sometimes characterized by the lifethreatening weakness of breathing muscles. The incidence of GBS is very low [43]. GBS and its variants/ subtypes were described in 42 COVID-19 patients up to June 30th [60], that is, 73 patients up to July 20th [61]. The mean interval between onset of COVID-19 and GBS symptoms was reported to be 11.5 days, thus confirming the classic post-infectious profile and the mechanisms of pathogenesis that are involved in all dysimmune neuropathies [61].

\section{OTHER CONSIDERATIONS}

Concerns have been raised that SARS-CoV-2 infection may have long-term consequences, similar to those humanity has encountered before, with other pathogens. A number of viruses have been implicated in the development of both multiple sclerosis [8] and Parkinson's disease [62], and thus it has been lately speculated on the possibility that SARS-CoV- 2 may serve as a trigger for these diseases [63]. Nevertheless, Parkinson's disease was associated with encephalitis, which is quite rare among COVID-19 patients [64]. It could be ungrateful, however, to dismiss any long-term neurological consequences of SARS-CoV-2 infection amidst an ongoing pandemic.

Since the start of the pandemic, health care systems around the world are often working beyond their capacities. For people living with disabilities, these circumstances created collateral damage in terms of access to health care services, including rehabilitation [65]. This means that chronic neurological patients receive less attention and care than before [66]. On the other hand, the total number of neuro-emergencies has fallen significantly since the onset of the pandemic $[67,68]$. However, it is noted that patients with neuroemergencies seek medical attention at later times than before the pandemic and that patients with neuroemergencies should be encouraged to regardless of the symptom severity [67].

Another important aspect of the COVID-19 pandemic is its impact on the growing population of people with age-associated neurodegenerative diseases such as Alzheimer's disease (AD) and related dementias, especially those accommodated in care facilities. In fact, a small Spanish study recorded a significant worsening of symptoms among patients with Alzheimer's disease (AD) and mild cognitive impairment [69]. In addition, while old age remains a risk factor for poor outcome in COVID-19 patients [70], statistics imply that older people with dementia are overrepresented in the group of deceased COVID-19 patients [71].
Aside from old age, genetic and environmental factors, as well as viral infections, may pose additional risks for the worsening of existing AD symptoms. Interestingly, the $A p o E$ e4 genotype, an established risk factor for AD [72] was recently found also to increase the risks of severe COVID-19 infection [73]. ApoE e4 affects lipoprotein function and cholesterol metabolism implicated in the pathogenesis of AD [74] and is one of the highly co-expressed genes with ACE2 in alveolar cells in the lungs [75]. Further investigation is needed to understand the link of AD risk factors to COVID-19 severity.

Pertinent to this, research is affected by this pandemic as well as every other aspect of our lives. The pandemic impacted current participants as well as the recruitment of new participants in clinical studies and trials related to dementia and AD [76, 77]. The impact of COVID-19 on basic neuroscience research and research, in general, is yet to be evaluated.

In conclusion, although there is little evidence that SARS-CoV-2 is neurotropic, neurological complications remain a serious issue for a portion of COVID-19 patients. These patients, as well as neurological patients in general, obviously demand special care and treatment, which is difficult to manage in overstrained health care systems. This increases the already heavy burden of COVID-19 pandemics, especially in low- and middle-income countries.

\section{REFERENCES}

1. Morgello S. Coronaviruses and the central nervous system. Journal of neurovirology. 2020.

2. Anthony SJ, Johnson CK, Greig DJ, Kramer S, Che X, Wells $\mathrm{H}$, et al. Global patterns in coronavirus diversity. Virus Evolution. 2017;3(1).

3. Wang Q, Zhang Y, Wu L, Niu S, Song C, Zhang Z, et al. Structural and Functional Basis of SARS-CoV-2 Entry by Using Human ACE2. Cell. 2020;181(4):894-904.e9.

4. Lai MMC, Stohlman SA. Molecular Basis of Neuropathogenicity of Mouse Hepatitis Virus. In: Roos RP, editor. Molecular Neurovirology: Pathogenesis of Viral CNS Infections. Totowa, NJ: Humana Press; 1992. p. 319-48.

5. Rissi DR. A retrospective study of the neuropathology and diagnosis of naturally occurring feline infectious peritonitis. Journal of veterinary diagnostic investigation : official publication of the American Association of Veterinary Laboratory Diagnosticians, Inc. 2018;30(3):392-9.

6. Körner RW, Majjouti M, Alcazar MAA, Mahabir E. Of Mice and Men: The Coronavirus MHV and Mouse Models as a Translational Approach to Understand SARS-CoV-2. Viruses. 2020;12(8):880..

7. Libbey JE, Cusick MF, Fujinami RS. Role of pathogens in multiple sclerosis. International reviews of immunology. 2014;33(4):266-83.

8. Bjelobaba I, Savic D, Lavrnja I. Multiple Sclerosis and Neuroinflammation: The Overview of Current and Prospective Therapies. Current Pharmaceutical Design. 2017;23(5):693-730. 
9. Chen R, Wang K, Yu J, Howard D, French L, Chen Z, et al. The spatial and cell-type distribution of SARS-CoV-2 receptor ACE2 in human and mouse brain. bioRxiv. 2020:2020.04.07.030650.

10. Somekh I, Yakub Hanna H, Heller E, Bibi H, Somekh E. Age-Dependent Sensory Impairment in COVID-19 Infection and its Correlation with ACE2 Expression. The Pediatric infectious disease journal. 2020;39(9):e270-e2.

11. Perlman S, Evans G, Afifi A. Effect of olfactory bulb ablation on spread of a neurotropic coronavirus into the mouse brain. Journal of Experimental Medicine. 1990;172(4):1127-32.

12. McCray PB, Jr., Pewe L, Wohlford-Lenane C, Hickey M, Manzel L, Shi L, et al. Lethal infection of K18-hACE2 mice infected with severe acute respiratory syndrome coronavirus. Journal of virology. 2007;81(2):813-21.

13. Netland J, Meyerholz DK, Moore S, Cassell M, Perlman S. Severe Acute Respiratory Syndrome Coronavirus Infection Causes Neuronal Death in the Absence of Encephalitis in Mice Transgenic for Human ACE2. Journal of Virology. 2008;82(15):7264-75.

14. Menachery VD, Yount BL, Sims AC, Debbink K, Agnihothram SS, Gralinski LE, et al. SARS-like WIV1-CoV poised for human emergence. Proceedings of the National Academy of Sciences. 2016;113(11):3048-53.

15. Rathnasinghe R, Strohmeier S, Amanat F, Gillespie VL, Krammer F, García-Sastre A, et al. Comparison of transgenic and adenovirus hACE2 mouse models for SARSCoV-2 infection. Emerg Microbes Infect. 2020;9(1):243345.

16. Hassan AO, Case JB, Winkler ES, Thackray LB, Kafai NM, Bailey AL, et al. A SARS-CoV-2 Infection Model in Mice Demonstrates Protection by Neutralizing Antibodies. Cell. 2020;182(3):744-53e4.

17. Klingenstein $M$, Klingenstein $S$, Neckel $P H$, Mack $A F$, Wagner A, Kleger A, et al. Evidence of SARS-CoV2 entry protein ACE2 in the human nose and olfactory bulb. bioRxiv 2020.07.15.204602; doi.org/10.1101/ 2020.07.15.204602. bioRxiv : the preprint server for biology. 2020:2020.07.15.204602.

18. Ding Y, He L, Zhang Q, Huang Z, Che X, Hou J, et al. Organ distribution of severe acute respiratory syndrome (SARS) associated coronavirus (SARS-CoV) in SARS patients: implications for pathogenesis and virus transmission pathways. J Pathol. 2004;203(2):622-30.

19. Gu J, Gong E, Zhang B, Zheng J, Gao Z, Zhong Y, et al. Multiple organ infection and the pathogenesis of SARS. J Exp Med. 2005;202(3):415-24.

20. Bohmwald K, Gálvez NMS, Ríos M, Kalergis AM. Neurologic Alterations Due to Respiratory Virus Infections. Front Cell Neurosci. 2018;12:386.

21. VanElzakker MB. Chronic fatigue syndrome from vagus nerve infection: A psychoneuroimmunological hypothesis. Medical Hypotheses. 2013;81(3):414-23.

22. DosSantos MF, Devalle S, Aran V, Capra D, Roque NR, Coelho-Aguiar JdM, et al. Neuromechanisms of SARS-CoV-2: A Review. Frontiers in Neuroanatomy. 2020;14(37).

23. Esposito G, Pesce M, Seguella L, Sanseverino W, Lu J, Sarnelli G. Can the enteric nervous system be an alternative entrance door in SARS-CoV2 neuroinvasion? Brain Behav Immun. 2020;87:93-4.

24. Kantonen J, Mahzabin S, Mäyränpää MI, Tynninen O, Paetau A, Andersson N, et al. Neuropathologic features of four autopsied COVID-19 patients. Brain pathology. 2020;30(6):1012-6.

25. Remmelink M, De Mendonca R, D'Haene N, De Clercq $S$, Verocq C, Lebrun L, et al. Unspecific post-mortem findings despite multiorgan viral spread in COVID-19 patients. Critical care. 2020;24(1):495.

26. Solomon IH, Normandin E, Bhattacharyya S, Mukerji SS, Keller K, Ali AS, et al. Neuropathological Features of Covid-19. New England Journal of Medicine. 2020; 383:989-92

27. Conklin J, Frosch MP, Mukerji S, Rapalino O, Maher M, Schaefer PW, et al. Cerebral Microvascular Injury in Severe COVID-19. medRxiv. 2020:2020.07.21.20159376.

28. Chougar L, Shor N, Weiss N, Galanaud D, Leclercq D, Mathon B, et al. Retrospective Observational Study of Brain MRI Findings in Patients with Acute SARS-CoV-2 Infection and Neurologic Manifestations. Radiology. 2020;297(3):E313-E23.

29. Kremer S, Lersy F, de Seze J, Ferre JC, Maamar A, CarsinNicol B, et al. Brain MRI Findings in Severe COVID-19: A Retrospective Observational Study. Radiology. 2020;297(2):E242-E51.

30. Hanley B, Naresh KN, Roufosse C, Nicholson AG, Weir J, Cooke GS, et al. Histopathological findings and viral tropism in UK patients with severe fatal COVID-19: a postmortem study. Lancet Microbe. 2020;1(6):e245-e53.

31. Song $E$, Zhang C, Israelow B, Lu-Culligan A, Prado AV, Skriabine $S$, et al. Neuroinvasion of SARS-CoV-2 in human and mouse brain. bioRxiv : the preprint server for biology. 2020:2020.06.25.169946.

32. Pellegrini $L$, Albecka A, Mallery DL, Kellner MJ, Paul D, Carter AP, et al. SARS-CoV-2 Infects the Brain Choroid Plexus and Disrupts the Blood-CSF Barrier in Human Brain Organoids. Cell Stem Cell. 2020;27(6):951-61 e5.

33. Wang W, Xu Y, Gao R, Lu R, Han K, Wu G, et al. Detection of SARS-CoV-2 in Different Types of Clinical Specimens. JAMA. 2020;323(18):1843-4.

34. Moriguchi T, Harii N, Goto J, Harada D, Sugawara H, Takamino J, et al. A first case of meningitis/encephalitis associated with SARS-Coronavirus-2. International Journal of Infectious Diseases. 2020;94:55-8.

35. Neumann B, Schmidbauer ML, Dimitriadis K, Otto S, Knier B, Niesen WD, et al. Cerebrospinal fluid findings in COVID-19 patients with neurological symptoms. Journal of the neurological sciences. 2020;418:117090.

36. Helms J, Kremer S, Merdji $H$, Schenck $M$, Severac F, Clere-Jehl R, et al. Delirium and encephalopathy in severe COVID-19: a cohort analysis of ICU patients. Critical care. 2020;24(1):491.

37. Alexopoulos H, Magira E, Bitzogli K, Kafasi N, Vlachoyiannopoulos P, Tzioufas A, et al. Anti-SARS-CoV-2 antibodies in the CSF, blood-brain barrier dysfunction, and neurological outcome: Studies in 8 stuporous and comatose patients. Neurology(R) neuroimmunology \& neuroinflammation. 2020;7(6).

38. Mao L, Jin H, Wang M, Hu Y, Chen $S$, He Q, et al. Neurologic Manifestations of Hospitalized Patients With Coronavirus Disease 2019 in Wuhan, China. JAMA neurology. 2020;77(6):1-9.

39. Varatharaj A, Thomas N, Ellul MA, Davies NWS, Pollak $\mathrm{TA}$, Tenorio EL, et al. Neurological and neuropsychiatric complications of COVID-19 in 153 patients: a UK-wide surveillance study. Lancet Psychiatry. 2020;7(10):875882. 
40. Li Y, Li M, Wang M, Zhou Y, Chang J, Xian Y, et al. Acute cerebrovascular disease following COVID-19: a single center, retrospective, observational study. Stroke Vasc Neurol. 2020;5(3):279-84.

41. Fan $S$, Xiao M, Han F, Xia P, Bai X, Chen H, et al. Neurological Manifestations in Critically III Patients With COVID-19: A Retrospective Study. Frontiers in neurology. 2020;11:806.

42. Scullen T, Keen J, Mathkour M, Dumont AS, Kahn L. Coronavirus 2019 (COVID-19)-Associated Encephalopathies and Cerebrovascular Disease: The New Orleans Experience. World neurosurgery. 2020;141:e437-46.

43. Nalleballe K, Reddy Onteddu S, Sharma R, Dandu V, Brown A, Jasti $M$, et al. Spectrum of neuropsychiatric manifestations in COVID-19. Brain Behav Immun. 2020;88:71-4.

44. Moro E, Priori A, Beghi E, Helbok R, Campiglio L, Bassetti $\mathrm{CL}$, et al. The international European Academy of Neurology survey on neurological symptoms in patients with COVID-19 infection. Eur J Neurol. 2020:10.1111/ ene.14407.

45. Rodriguez-Morales AJ, Cardona-Ospina JA, Gutiérrez-Ocampo $E$, Villamizar-Peña $R$, Holguin-Rivera $Y$, Escalera-Antezana JP, et al. Clinical, laboratory and imaging features of COVID-19: A systematic review and meta-analysis. Travel Medicine and Infectious Disease. 2020;34:101623.

46. Niazkar HR, Zibaee B, Nasimi A, Bahri N. The neurological manifestations of COVID-19: a review article. Neurol Sci. 2020;41(7):1667-71.

47. Chen N, Zhou M, Dong X, Qu J, Gong F, Han Y, et al. Epidemiological and clinical characteristics of 99 cases of 2019 novel coronavirus pneumonia in Wuhan, China: a descriptive study. Lancet. 2020;395(10223):507-13.

48. Sharifi-Razavi A, Karimi N, Rouhani N. COVID-19 and intracerebral haemorrhage: causative or coincidental? New microbes and new infections. 2020;35:100669.

49. Wu T, Zuo Z, Kang S, Jiang L, Luo X, Xia Z, et al. Multi-organ Dysfunction in Patients with COVID-19: A Systematic Review and Meta-analysis. Aging Dis. 2020;11(4):874-94.

50. Parry AH, Wani AH, Yaseen M. Neurological Dysfunction in Coronavirus Disease-19 (COVID-19). Acad Radiol. 2020;27(9):1329-30.

51. Chen T, Wu D, Chen H, Yan W, Yang D, Chen G, et al. Clinical characteristics of 113 deceased patients with coronavirus disease 2019: retrospective study. BMJ. 2020;368:m1091.

52. Engelhardt S, Patkar S, Ogunshola OO. Cell-specific blood-brain barrier regulation in health and disease: a focus on hypoxia. Br J Pharmacol. 2014;171(5):1210-30.

53. Willekens B, Cras P, Crosiers D. Myoclonus and cerebellar ataxia following Coronavirus Disease 2019 (COVID-19). Movement disorders clinical practice. 2020;7(8):974-6.

54. Fadakar N, Ghaemmaghami S, Masoompour SM, Shirazi Yeganeh B, Akbari A, Hooshmandi S, et al. A First Case of Acute Cerebellitis Associated with Coronavirus Disease (COVID-19): a Case Report and Literature Review. Cerebellum. 2020;19(6):911-4.

55. Zhang T, Rodricks MB, Hirsh E. COVID-19-Associated Acute Disseminated Encephalomyelitis: A Case Report. medRxiv : the preprint server for health sciences. 2020:2020.04.16.20068148.
56. Mullol J, Alobid I, Mariño-Sánchez F, Izquierdo-Domínguez A, Marin C, Klimek L, et al. The Loss of Smell and Taste in the COVID-19 Outbreak: a Tale of Many Countries. Current allergy and asthma reports. 2020;20(10):61.

57. Zubair AS, McAlpine LS, Gardin T, Farhadian S, Kuruvilla DE, Spudich $S$. Neuropathogenesis and Neurologic Manifestations of the Coronaviruses in the Age of Coronavirus Disease 2019: A Review. JAMA neurology. 2020;77(8):1018-27.

58. Brann DH, Tsukahara T, Weinreb C, Logan DW, Datta SR. Non-neural expression of SARS-CoV-2 entry genes in the olfactory epithelium suggests mechanisms underlying anosmia in COVID-19 patients. bioRxiv : the preprint server for biology. 2020:2020.03.25.009084.

59. Xu H, Zhong L, Deng J, Peng J, Dan H, Zeng X, et al. High expression of ACE2 receptor of 2019-nCoV on the epithelial cells of oral mucosa. Int J Oral Sci. 2020;12(1):8.

60. Uncini A, Vallat JM, Jacobs BC. Guillain-Barré syndrome in SARS-CoV-2 infection: an instant systematic review of the first six months of pandemic. Journal of neurology, neurosurgery, and psychiatry. 2020;91(10):1105-10.

61. Abu-Rumeileh $\mathrm{S}$, Abdelhak A, Foschi M, Tumani H, Otto M. Guillain-Barré syndrome spectrum associated with COVID-19: an up-to-date systematic review of 73 cases. Journal of neurology. 2020:1-38.

62. Jang H, Boltz DA, Webster RG, Smeyne RJ. Viral parkinsonism. Biochim Biophys Acta. 2009;1792(7):714-21.

63. Schirinzi T, Landi D, Liguori C. COVID-19: dealing with a potential risk factor for chronic neurological disorders. Journal of neurology. 2020:1-8.

64. Sulzer D, Antonini A. COVID-19 and possible links with Parkinson's disease and parkinsonism: from bench to bedside. NPJ Parkinsons Dis. 2020;6:18.

65. Boldrini P, Garcea M, Brichetto G, Reale N, Tonolo S, Falabella $V$, et al. Living with a disability during the pandemic. "Instant paper from the field" on rehabilitation answers to the COVID-19 emergency. European journal of physical and rehabilitation medicine. 2020;56(3):331-4.

66. Barry $\mathrm{HE}$, Hughes $\mathrm{CM}$. Managing medicines in the time of COVID-19: implications for community-dwelling people with dementia. International journal of clinical pharmacy. 2021;43(1):275-9..

67. Hecht N, Wessels L, Werft F-O, Schneider UC, Czabanka $M$, Vajkoczy P. Need for ensuring care for neuro-emergencies-lessons learned from the COVID-19 pandemic. Acta Neurochir (Wien). 2020;162(8):1795-801.

68. Figueroa JM, Boddu J, Kader M, Berry K, Kumar V, Ayala V, Vanni S, Jagid J. The Effects of Lockdown During the Severe Acute Respiratory Syndrome Coronavirus 2 (SARS-CoV-2) Pandemic on Neurotrauma-Related Hospital Admissions. World Neurosurg. 2020;S18788750(20)31850-7.

69. Lara B, Carnes A, Dakterzada F, Benitez I, Piñol-Ripoll G. Neuropsychiatric symptoms and quality of life in Spanish patients with Alzheimer's disease during the COVID-19 lockdown. Eur J Neurol. 2020;27(9):1744-7.

70. Verity R, Okell LC, Dorigatti I, Winskill P, Whittaker C, Imai $\mathrm{N}$, et al. Estimates of the severity of coronavirus disease 2019: a model-based analysis. The Lancet Infectious Diseases. 2020;20(6):669-77. 
71. Livingston G, Huntley J, Sommerlad A, Ames D, Ballard $C$, Banerjee $S$, et al. Dementia prevention, intervention, and care: 2020 report of the Lancet Commission. Lancet. 2020;396(10248):413-46.

72. Yu JT, Tan L, Hardy J. Apolipoprotein E in Alzheimer's disease: an update. Annual review of neuroscience. 2014;37:79-100.

73. Kuo CL, Pilling LC, Atkins JL, Masoli JAH, Delgado J, Kuchel GA, et al. APOE e4 genotype predicts severe COVID-19 in the UK Biobank community cohort. The journals of gerontology Series A, Biological sciences and medical sciences. 2020;75(11):2231-2.

74. Smiljanic K, Loncarevic-Vasiljkovic N, Kanazir S, Mladenovic Djordjevic A. Cholesterol in Brain Health and Pathologies: The Role in Alzheimer's Disease. In: Atta-
ur-Rahman, editor. Frontiers in Clinical Drug Research - Alzheimer Disorders. 9: Bentham Science Publishers; 2019. p. 1-52.

75. Zhao Y, Zhao Z, Wang Y, Zhou Y, Ma Y, Zuo W. Single-cell RNA expression profiling of ACE2, the putative receptor of Wuhan 2019-nCov. bioRxiv : the preprint server for biology. 2020:2020.01.26.919985.

76. Bardach SH, Gibson AK, Rhodus EK, Jicha GA. Will "social distancing" lead to future "research distancing": A reflection on COVID-19 impacts on Alzheimer's disease research. Alzheimer's \& dementia (New York, N Y). 2020;6(1):e12045.

77. Bostanciklioglu M. Severe Acute Respiratory Syndrome Coronavirus 2 is Penetrating to Dementia Research. Current neurovascular research. 2020;17(4):342-3.

\section{Neurološki poremećaji i pandemija COVID-19}

\author{
Ivana Bjelobaba, Selma Kanazir \\ Odeljenje za neurobiologiju, Institut za \\ biološka istraživanja "Siniša Stanković" \\ - Institut od nacionalnog značaja za \\ Republiku Srbiju, Univerzitet u Beogradu, \\ Bulevar despota Stefana 142, 11000 \\ Beograd, Srbija
}

\begin{abstract}
Kratak sažetak
Sve veci broj podataka ukazuje na to da infekcija virusom SARS-CoV-2 može uticati na nervni sistem. Ovde predstavljamo kratak, uzdržan pregled opisanih neuroloških oštećenja povezanih sa SARS-CoV-2 infekcijom. lako je očigledno da se neurološki poremećaji mogu dijagnostikovati kod dela COVID-19 pacijenata, čvrsti dokazi o neurovirulenciji SARS-CoV-2 još uvek nedostaju. Postojeci podaci o učestalosti neuroloških poremećaja među COVID-19 pacijentima veoma su raznoliki, verovatno zato što (najčešće) potiču iz malih, unicentričnih retrospektivnih studija. Ovi podaci se praktično objavljuju u realnom vremenu i ostaje pitanje kada će biti dostupne veće studije, sobzirom na to da se pandemija nastavlja. Ovde se ukratko bavimo i drugim pitanjima u vezi sa neurološkim poremećajima i pandemijom COVID-19, uključujući tu i uticaj pandemije na ljude sa postojećim hroničnim neurološkim poremećajima i moguće dugoročne neurološke posledice infekcije SARS-CoV-2.
\end{abstract}

KIjučne reči: SARS-CoV-2; COVID-19; Neurotropizam; Neurološki poremećaji. 